\title{
Expression of CD21 and CD23 during Human Fetal Development
}

\author{
CATHERINE A. THORNTON, JUDITH A. HOLLOWAY, AND JOHN O. WARNER \\ Allergy and Inflammation Sciences, School of Medicine, University of Southampton, SO16 6YD, U.K.
}

\begin{abstract}
Neonates produce lower levels of IgE compared with adults. Diminished IL-4 production and impaired up-regulation of CD40L by neonatal $\mathrm{T}$ cells could explain this, however other regulators of $\mathrm{IgE}$ production, such as $\mathrm{CD} 21$ and $\mathrm{CD} 23$, could contribute to reduced circulating IgE levels during fetal development. Heparinized blood samples were collected from adults and from the umbilical cord at premature and term births. Whole blood flow cytometry was used to assess the percentage of $\mathrm{T}$ $\left(\mathrm{CD}^{+}\right)$and $\mathrm{B}\left(\mathrm{CD} 19^{+}\right)$lymphocytes expressing $\mathrm{CD} 21$ and/or $\mathrm{CD} 23$ at $26-29(n=3), 30-33(n=7), 34-37(n=5)$, and $>37$ $(n=11)$ wk of gestation, as well as in adults $(n=15)$. Plasma-soluble CD21 was also measured. At term, the percentage of $\mathrm{CD} 21^{+}$and $\mathrm{CD} 23^{+} \mathrm{B}$ cells was comparable to the adult, however, the percentage of cells positive for each of these surface antigens was decreased significantly before term. The percentage of $\mathrm{T}$ cells expressing CD21 from all gestations was significantly higher than the adult and the percentage positive
\end{abstract}

ABSTRACT

decreased with increasing gestational age. Conversely, soluble CD21 levels increased with increasing gestation to be comparable to the adult by term. Thus, it is unlikely that altered expression of CD21 and CD23 on B cells contributes to the low level of $\operatorname{IgE}$ in the neonatal circulation unless functional differences occur or a lack of processing to the soluble form is important in regulating IgE production. However the abundance of CD21positive $\mathrm{T}$ cells could alter the $\mathrm{T}$ - and $\mathrm{B}$-cell interaction necessary for IgE switching by B cells and, thereby, especially with impaired IL-4 production, limit IgE production. (Pediatr Res 52: 245-250, 2002)
sCD21, soluble CD21
sCD23, soluble CD23
CD40L, CD40 ligand (CD154)

\section{Abbreviations}

Isotype switching to IgE production by human B cells requires a well-coordinated series of events. Thus IL-4 (and to a lesser extent IL-13) and the cognate interaction of B cell (CD40) with T cell (CD40L, CD154) have now been identified as the minimal requirements for the transcription of germline epsilon message and secretion of $\operatorname{IgE}(1,2)$. $\operatorname{IgE}$ levels in the circulation of neonates born in Westernized countries are characteristically very low, ranging from not detectable to $<2$ $\mathrm{IU} / \mathrm{mL}(3,4)$. Nevertheless, as IgE does not traverse the placenta $(5,6), \mathrm{IgE}$ in the fetal circulation probably represents fetal production, although, as IgE is detectable in amniotic fluid where it might be of maternal origin (7), any $\operatorname{IgE}$ detected in the fetal circulation could reflect IgE of both fetal and maternal origin. IgE production by fetal tissues has been demonstrated to occur in the fetal liver and lung from as early as $11 \mathrm{wk}$ of gestation, and by $21 \mathrm{wk}$ of gestation explants of fetal spleen can also synthesize $\operatorname{IgE}(8)$. Active transcription of sterile I $\epsilon$

Received July 5, 2001; accepted December 27, 2001.

Correspondence: Dr. Catherine A. Thorton (née Jones), Child Health, Level G Centre Block (803), Southampton General Hospital, Southampton, SO16 6YD, U.K.; e-mail: caj@soton.ac.uk

Supported by Grant HL61858 from the National Institutes of Health.

DOI: 10.1023/01.PDR.0000023172.89966.50 occurs in the liver, spleen mesentery and gut as early as $8 \mathrm{wk}$ of gestation but VDJC $\epsilon$ transcripts cannot be detected until 18 wk of gestation (in two of 18 fetal liver samples) (9) and circulating IgE cannot be detected until $25 \mathrm{wk}$ of gestation (Jones et al., submitted). As total IgE levels can be very high in neonates born in countries where parasitosis still occurs (10), the neonate is obviously not impervious to production of adult equivalent levels. Furthermore, the ability to detect allergen- and parasite-specific IgE at birth $(10,11)$ implies that isotype switching of $\mathrm{B}$ cells in response to antigen can occur during fetal life. However, very little is known about the regulation of $\mathrm{IgE}$ production by the fetus and neonate.

The lower production of IgE by neonatal B cells has catalyzed numerous analyses of B- and T-cell phenotype. Neonatal B-cell expression of CD40 is similar to the adult (12), and responses to CD40 stimulation can be induced $(13,14)$. Expression of CD40 ligand (CD40L, CD154) is variably described as reduced or comparable to the adult, depending upon the stimulation used $(12,13,15-19)$. In contrast, IL-4 production by umbilical cord blood mononuclear cells is consistently described as lower than that from adult peripheral blood mononuclear cells, irrespective of the stimulus used $(14,20)$. The lack of IL-4 and/or CD40 ligand may be the limiting factor in 
$\operatorname{IgE}$ production by the neonate, as a number of investigators have found that exogenous IL-4 in conjunction with CD40 cross-linking increased IgE production by umbilical cord blood mononuclear cells $(13,14,16,17)$.

The interaction of CD23 and CD21 has also been shown to have an important role in IgE production and is considered to control IgE production in a more isotype-specific fashion (2). Therefore, altered expression or function of other IgE regulatory molecules such as the ligand pair CD23 and CD21 could also contribute to the poor production of IgE by Western neonates. CD23 is a $45-\mathrm{kD}$ type II membrane glycoprotein that in humans occurs as two different isoforms, a (constitutively expressed on $\mathrm{B}$ cells) and $\mathrm{b}$ (up-regulated on B and other hematopoietic stimuli such as IL-4), and serves as the lowaffinity IgE receptor. Membrane CD23 has a role in downregulation of IgE production $(21,22)$. CD21 is a $140-\mathrm{kD}$ membrane glycoprotein predominantly expressed by B lymphocytes and follicular dendritic cells and is a receptor for CD23. The occupancy of CD21 on B cells enhances IgE production (23). The CD21/CD23 ligand pair is poorly studied in the neonate, therefore, we undertook an investigation of the developmental regulation of $\mathrm{CD} 21$ and $\mathrm{CD} 23$ pair during the third trimester of pregnancy.

\section{MATERIALS AND METHODS}

Samples. Fetal blood was collected by umbilical vein or cardiac puncture from fetuses delivered for medical reasons using prostin with informed consent from the mother. Blood was also collected by umbilical vein puncture from neonates delivered at term and prematurely and by venepuncture from healthy adult controls with informed consent where appropriate. All bloods were collected into lithium heparin (Vacutainer, BD Biosciences, Franklin Lakes, NJ, U.S.A.) and samples were processed within $3 \mathrm{~h}$ of collection. None of the premature infants were known to have abnormalities of the immune system at birth. Whole blood was used for flow cytometry as described below and plasma was obtained after density gradient centrifugation of undiluted blood on Histopaque (Sigma Chemical, Poole, Dorset, U.K.) (cells were used for other studies). Plasma was filtered, aliquoted, and stored at $-80^{\circ} \mathrm{C}$ until analysis. The study was approved by the Southampton and S.W. Hants Joint Research Ethics Committee and fulfilled the requirements of the Polkinghorne Committee report on the research use of fetuses and fetal tissues.

Flow cytometry. Whole blood $(50 \mu \mathrm{L})$ was placed in a fluorescence-activated cell sorter (FACS) tube with a preoptimized concentration of fluorochrome-conjugated antibodies and incubated in the dark and on ice for $30 \mathrm{~min}$. Red blood cell lysis was conducted by the addition of $2 \mathrm{~mL}$ of $1 \times$ FACS Lysing Solution (BD Biosciences) and incubation at room temperature for $12 \mathrm{~min}$. After centrifugation at $400 \times g$ at $4^{\circ} \mathrm{C}$ for $7 \mathrm{~min}$, the pellet was washed twice by centrifugation with $3 \mathrm{~mL}$ PBS $/ 0.5 \%$ BSA $/ 0.2 \%$ sodium azide. The pellet was resuspended in $100 \mu \mathrm{L}$ of $1 \%$ paraformaldehyde and stored in the dark at $4^{\circ} \mathrm{C}$ until acquisition by flow cytometry (FACScan, BD Biosciences) within $2 \mathrm{~d}$ of staining. The population identified by characteristic side scatter and CD3 or CD19-positivity was acquired (5,000-10,000 events, with total events collected and saved) for analysis using CellQuest software (BD Biosciences). The following antibodies (Ancell, Alexis Corporation, Nottingham, U.K.) were used for this study: anti-CD19 conjugated to FITC (mIgG1, clone BU12), anti-CD3 conjugated to FITC (mIgG1, clone UCHT1), anti-CD23 conjugated to R-phycoerythrin (mIgG1, clone BU38), and anti-CD21 conjugated to R-phycoerythrin (mIgG1, clone BU33). An isotype control was included as appropriate (mIgG1, clone MOPC-21, BD PharMingen, San Diego, CA, U.S.A.).

ELISA. Plasma sCD21 levels were measured with a specific ELISA (Diatec, IDS Ltd, Tyne and Wear, U.K.) according to the manufacturer's instructions. All samples were assayed after a 1:2 dilution in the sample buffer provided with the kit and the sensitivity of the assay was $3 \mathrm{U} / \mathrm{mL}$.

Statistical analysis. The percentage of $\mathrm{CD} 23^{+}$or $\mathrm{CD} 21^{+}$ cells (B or $\mathrm{T}$ ) in each group was compared using Mann Whitney $U$ test and the maturation of $\mathrm{SCD} 21$ was assessed using Kruskall-Wallis (SPSS, Version 8.0, SPSS Inc., Chicago, IL, U.S.A.; StatView, Version 5.0, SAS, Cary, NC, U.S.A.).

\section{RESULTS}

Expression of CD23 and CD21 on $\mathrm{CD}^{+}{ }^{+} \mathrm{B}$ cells. B cells were identified by their characteristic side-scatter profile and CD19 positivity (Fig. 1a). After setting a gate on this population (R1), 3000-5000 events within the gate were acquired and analyzed. Examples of results for CD21 expression (Fig. 1c) and CD23 expression (Fig. 1d) as well as the isotype control (Fig. 1b) are shown for both adult peripheral and for umbilical cord blood. At term ( $>37 \mathrm{wk}$ of gestation, $n=11)$, the percentage of B cells expressing CD23 was comparable to the adult $(n=13$, Fig. $2 a)$, with the percentage of $\mathrm{CD} 23^{+} \mathrm{B}$ cells at earlier gestational ages reduced in comparison to the levels at term and in the adult. Statistically significant differences were observed for the differences between adults and 26-29 ( $n$ $=3, p=0.039)$ and 30-33 $(n=7 ; p=0.03)$ wk of gestation, and only for 30-33 wk of gestation compared with the term neonate $(p=0.02)$ (Fig. $2 a)$. Similarly, the percentage of $\mathrm{CD} 21^{+} \mathrm{B}$ cells was comparable in the adult $(n=15)$ and term $(n=11)$ neonate and significantly lower at 26-29 $(n=3, p=$ $0.005), 30-33(n=6, p=0.003)$, and 34-37 $(n=4, p=$ $0.027)$ wk of gestation compared with the term neonate, and at $26-29(p=0.027)$ and $30-33(p=0.036)$ wk the percentage of $\mathrm{CD} 21^{+} \mathrm{B}$ cells was significantly reduced in comparison to adults (Fig. 2b).

Expression of CD21 on T lymphocytes. T cells were identified by their characteristic side scatter and CD3 expression (Fig. 3a). Events $(10,000)$ within the gate (R1) were acquired and analyzed. Examples of the results obtained for adult and umbilical cord blood for both the isotype control (Fig. 3b) and $\mathrm{CD} 21$ (Fig. $3 c$ ) are shown. In contrast to adult $\mathrm{CD} 3^{+}$cells that were virtually devoid of membrane CD21 expression, umbilical cord blood $\mathrm{CD}^{+}$cells had a distinct subpopulation of $\mathrm{CD} 21^{+}$cells. The percentage of $\mathrm{CD} 3^{+}$cells expressing CD21 decreased with increasing gestational age but remained significantly higher than adult levels at all gestational time points examined [26-29 wk $(n=3), p=0.012 ; 30-33 \mathrm{wk}(n=5)$, 
1(a)

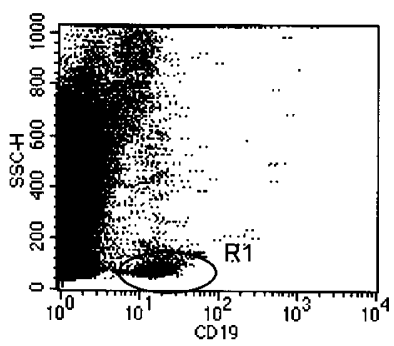

1(b)

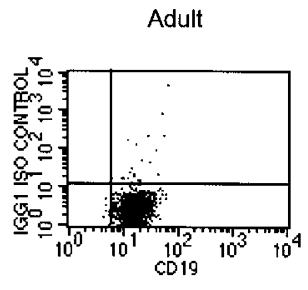

1(c)

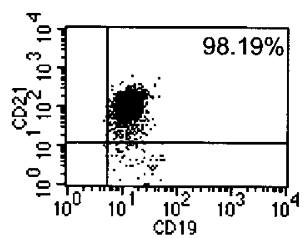

1 (d)

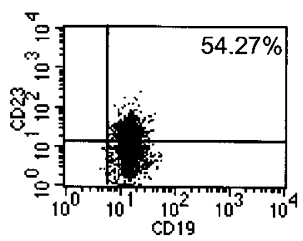

Cord
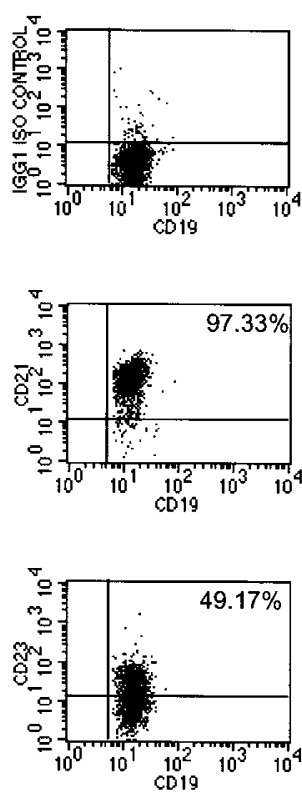

Figure 1. The identification of B cells expressing CD23 and CD21. B cells were $(a)$ identified by their characteristic side-scatter profile and CD19 positivity, and then 3000-5000 events $(R 1)$ were analyzed with phycoerythrinconjugated $(b)$ isotype control $(\mathrm{mIgG1}),(c)$ anti-CD21, or $(d)$ anti-CD23 control. Examples of results obtained with umbilical cord and adult blood are shown.

$p=0.002 ; 34-37 \mathrm{wk}(n=4), p=0.016 ;>37 \mathrm{wk}(n=6), p$ $=0.001$ compared with adults $(n=8)]$. At the earliest time points examined in this study, 26-29 and 30-33 wk, 28.9\% and $28.2 \%$, respectively, of the $\mathrm{CD}^{+}$cells expressed CD 21 , and by $34-37 \mathrm{wk}$ and term $(>37 \mathrm{wk}$ of gestation) this had decreased to $16.2 \%$ and $19.4 \%$, respectively, of the $\mathrm{CD}^{+}$ cells. There was no significant difference between the fetal/ neonatal samples at different gestational ages (Fig. $4 a$ ). Subset analysis revealed that the increased expression of $\mathrm{CD} 21$ by fetal/neonatal $\mathrm{T}$ cells occurred to a greater extent on the $\mathrm{CD} 8^{+}$ subset of $\mathrm{T}$ lymphocytes in comparison to $\mathrm{CD} 4^{+}$subset (Fig. $4 b)$.

Levels of sCD21. As there were more $\mathrm{CD} 21^{+} \mathrm{T}$ cells in the fetal/neonatal circulation and $\mathrm{T}$ lymphocytes are considered the major source of plasma sCD21 (24), we measured the levels of sCD21 in fetal and neonatal plasma. Samples collected during this study as well as archived fetal plasma samples from very early in gestation (16-25 wk of gestation) were used. Plasma levels of the soluble form of CD21 showed a significant
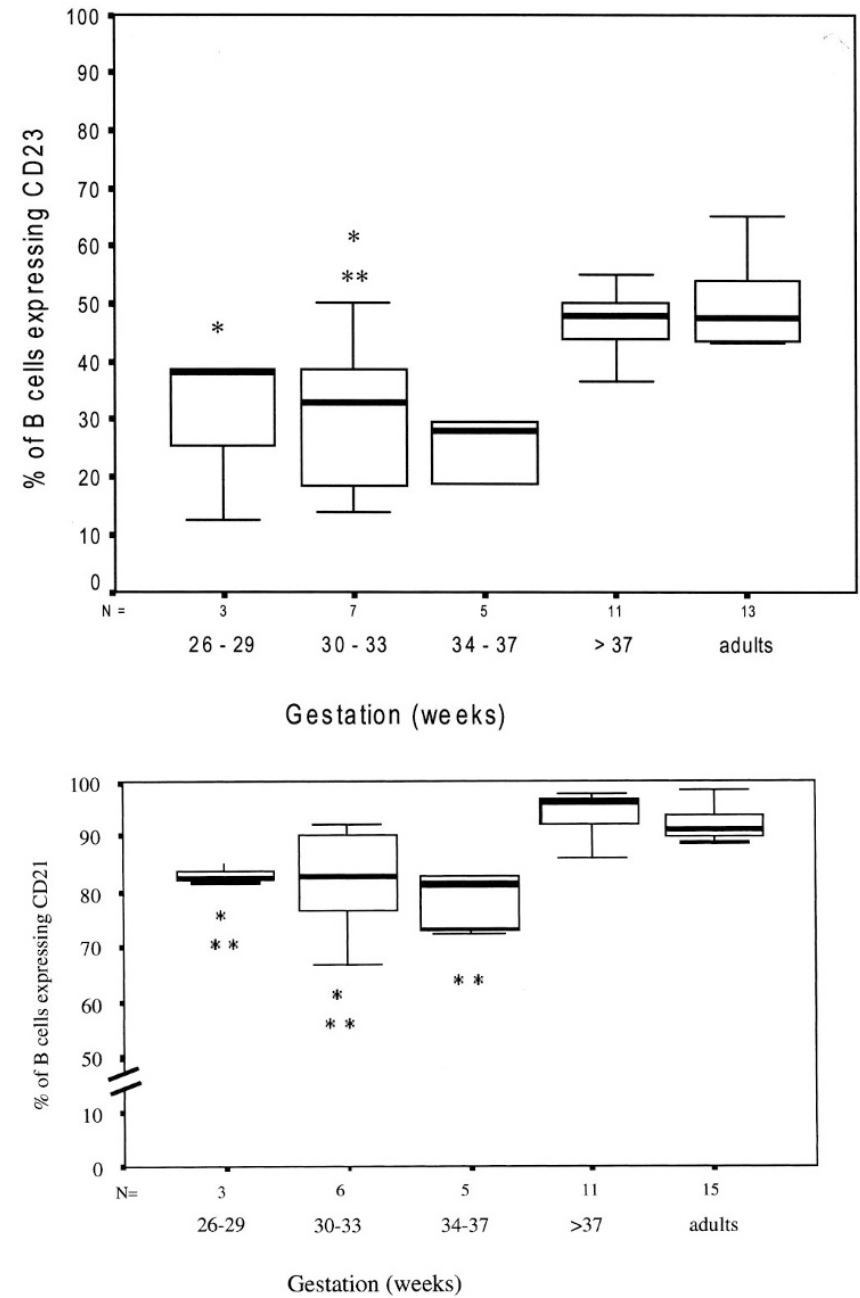

Figure 2. The percentage of $B$ cells expressing CD23 and CD21 over gestation. Flow cytometry was used to determine the percentage of B cells from fetuses/neonates of different gestations and adults expressing (a) CD23 and $(b)$ CD21. *Significant difference $(p<0.05)$ compared with the adult; **significant difference compared with term.

increase over gestation to be comparable to the adult by $34-37$ wk of gestation (Fig. 5; $p=0.007$, Kruskall-Wallis).

\section{DISCUSSION}

This is the first study to describe CD23 and CD21 expression by umbilical cord blood mononuclear cells at term $(>37 \mathrm{wk}$ of gestation) and preterm birth (26-37 wk of gestation). The percentages of $\mathrm{CD} 23^{+}$or $\mathrm{CD} 21^{+} \mathrm{B}$ cells were comparable between term samples and the adult, but there was clearly "maturation" of the percentage of B cells positive for CD23 and, to a lesser extent, CD21 over the third trimester of pregnancy. The most striking difference between the adult and fetal/neonatal samples was the increased percentage of $\mathrm{CD}^{+}$ $\mathrm{T}$ cells expressing CD21 and the reduced levels of sCD21 in the fetal circulation. Surface expression of CD21 by the $\mathrm{CD} 3^{+}$ population decreased in contrast to soluble levels that increased with increasing gestational age.

Membrane CD23 negatively regulates IgE production (21, $22,25)$, whereas the soluble form ( $\mathrm{sCD} 23)$, derived by proteo- 


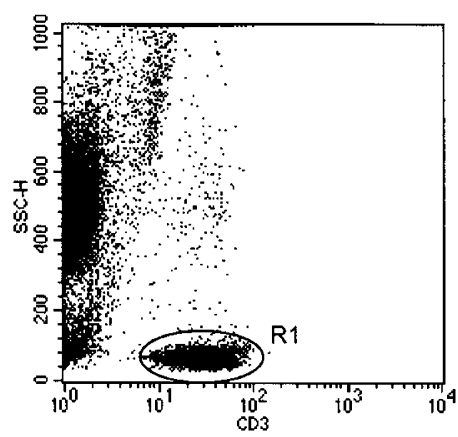

3(b) Adult
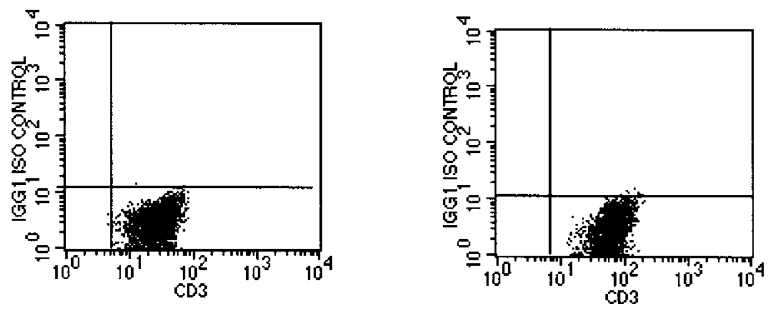

$3(\mathrm{c})$

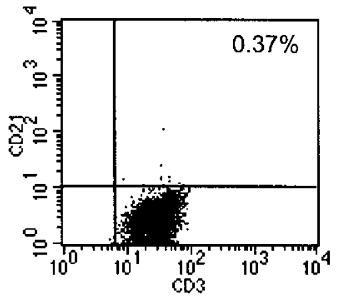

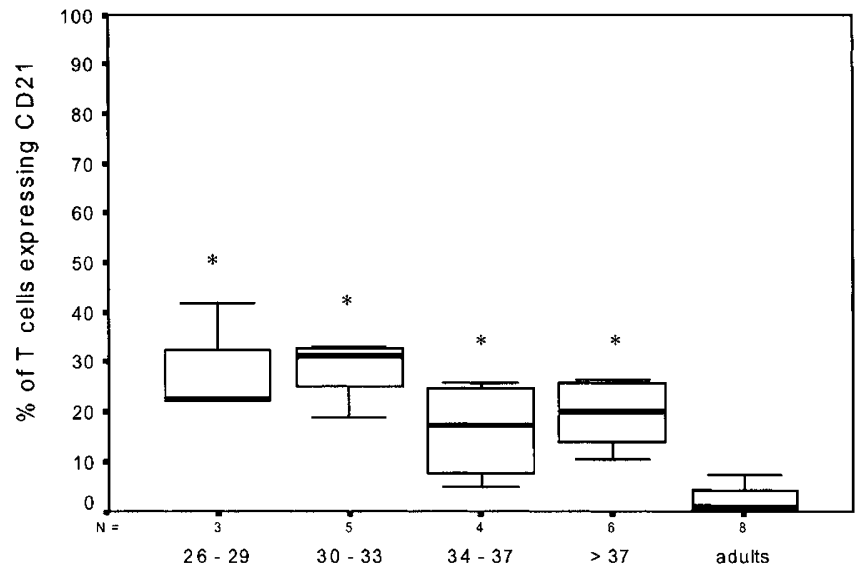

Gestation (weeks)

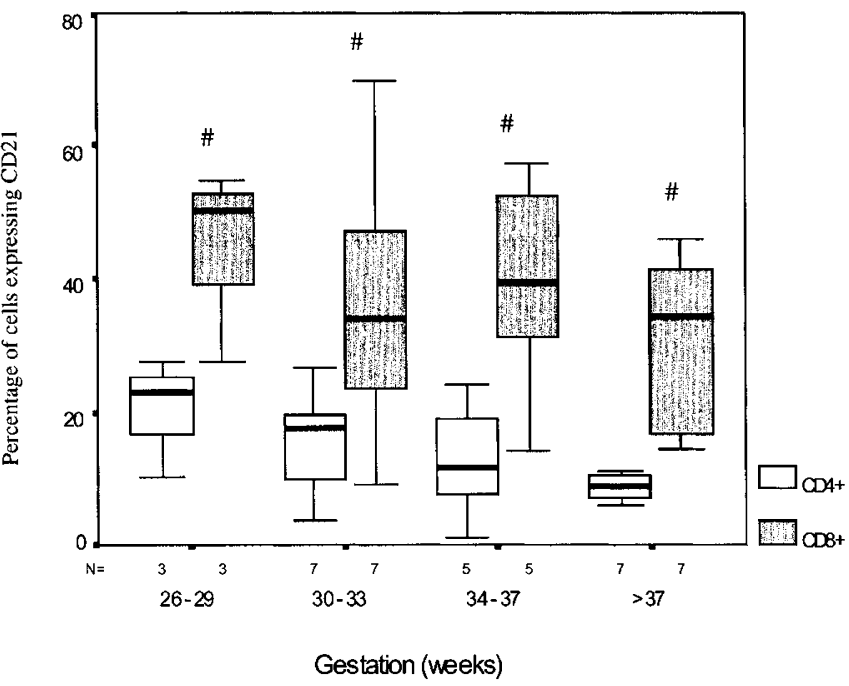

Figure 4. The percentage of $\mathrm{T}$ cells expressing CD21 over gestation. Flow cytometry was used to determine the percentage of $(a) \mathrm{CD}^{+} \mathrm{T}$ cells and $(b)$ $\mathrm{CD}^{+}$compared with $\mathrm{CD} 8^{+} \mathrm{T}$ cells from fetuses/neonates of different gestation and adults expressing CD21. *Significant difference compared with adults ( $p<0.02$, see text for values); ${ }^{\#}$ significant difference between the percentage of $\mathrm{CD} 4^{+} / \mathrm{CD} 21^{+}$compared with $\mathrm{CD} 8^{+} / \mathrm{CD} 21^{+}$cells at the same gestation $(b)$. lymphocytes (25) in which inhibition of the release of CD23 from the cell surface inhibited IL-4-induced IgE production. Moreover, the release of $\mathrm{sCD} 23$ was found to precede $\operatorname{IgE}$ production. In the current study, the percentage of $\mathrm{CD} 23^{+} \mathrm{B}$ cells as well as the density of expression, mean fluorescence intensity (data not shown), was similar in the adult and term neonate. Thus, it is unlikely that altered membrane CD23 expression is contributing to the very low levels of circulating IgE that occur in the neonate. In contrast to membrane CD23, sCD23 enhances IgE production $(22,25)$. Soluble CD23 levels were not examined in this study, but, in a previous study, cord sCD23 levels were reduced compared with the adult (27). As the processing of $\mathrm{mCD} 23$ to $\mathrm{sCD} 23$ may have an IgEenhancing effect (25), restriction of this pathway on fetal/ neonatal B cells could contribute to reduced IgE production.

The only other study to consider CD23 expression during gestation used RT-PCR to show that transcripts for both CD23a and $\mathrm{b}$ were present from as early as $8 \mathrm{wk}$ of gestation in the liver, spleen, mesentery, and gut (9). Furthermore, approximately $70 \%$ of cord blood samples from the second trimester (14-26 wk) contained transcripts for CD23a and CD23b. In the third trimester, nearly all samples expressed mRNA for CD23a and 60\% expressed mRNA for CD23b. As we used flow cytometry to study CD23 expression, it is not possible to differentiate between the two isoforms of CD23, as they differ in the N-terminal cytoplasmic region, however, it is likely that the expression we were assessing on B cells is the constitutively expressed CD23a isoform.

The only CD23 ligand examined in this study was CD21. The number of B cells expressing CD21 clearly increased over gestation and, most strikingly, the percentage of $\mathrm{T}$ cells expressing CD21 was much higher than in adulthood. There are reports of the expression of CD21 by $\mathrm{T}$ cells from adult peripheral blood (28). However, other studies indicate that, although the levels of transcripts for CD21 are comparable between adult peripheral blood T and B cells (29), circulating adult $\mathrm{T}$ cells do not express detectable levels of membrane 


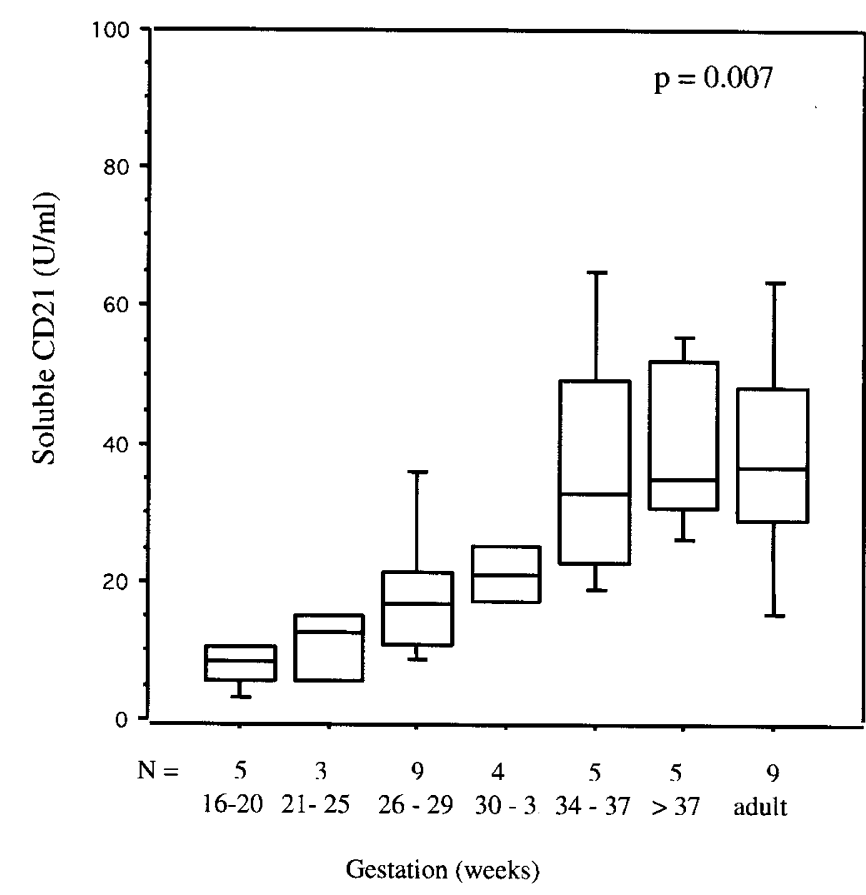

Figure 5. Plasma-soluble CD21. The level of soluble CD21 in plasma from fetuses and neonates of different gestational ages and adults was measured by specific ELISA. The trend to increased plasma sCD21 over gestation was significant ( $p=0.007$, Kruskall-Wallis).

CD21 (29, this study). Still, up to $70 \%$ of normal human thymocytes express CD21 $(30,31)$, and it has been suggested that CD21 could have a role in the proliferation and differentiation of $\mathrm{T}$ cells in the very early stages of maturation. Thus, the CD21 expression we observed on fetal/neonatal $\mathrm{T}$ cells could reflect the immaturity of the T-cell population, indicating recent emigration from the thymus. Other phenotypic markers, e.g. the greater percentage of $\mathrm{CD} 38^{+} \mathrm{T}$ cells in the neonatal circulation (32), also indicate that cord blood $\mathrm{T}$ cells are immature.

To address this further, we considered the expression of $\mathrm{CD} 21$ by the $\mathrm{CD}^{+}$and $\mathrm{CD}^{+}$T-cell subsets in the fetal/ neonatal blood as the expression of CD21 was more marked on $\mathrm{CD}^{+}$compared with $\mathrm{CD} 4^{+}$thymocytes $(31)$. The percentage of $\mathrm{CD}^{+} / \mathrm{CD} 21^{+}$cells was significantly greater than $\mathrm{CD} 4^{+} /$ $\mathrm{CD} 21^{+}$, further supporting the postulate that the expression of CD21 by fetal/neonatal $\mathrm{T}$ cells is a marker of immaturity. The congruency of increased surface CD21 on the $\mathrm{T}$ cells and reduced circulating levels makes it tempting to speculate that the difference reflects changes in the pattern of cleavage of membrane CD21 in neonatal compared with adult $\mathrm{T}$ cells. Soluble CD21 is formed by protease-mediated cleavage of the extracellular portion of membrane CD21, and in vitro studies reveal a parallel decrease in surface expression with increasing levels in supernatants (24).

The comparable percentages of $\mathrm{CD} 21^{+}$and $\mathrm{CD} 23^{+} \mathrm{B}$ cells at term birth and adulthood make it unlikely (unless there are functional differences) that altered expression of these contribute to reduced $\mathrm{IgE}$ production by the full-term neonate. However, a common feature of the fetus/neonate may be reduced levels of proteolytic cleavage of both $\mathrm{mCD} 21$ and $\mathrm{mCD} 23$ that might limit IgE production. Although occupancy of CD21 on B cells (using MAb or sCD23) enhances IgE production (21), the effect of T-cell-associated CD21 on IgE production is unknown, so it is not possible to determine yet whether the $\mathrm{CD} 21^{+} \mathrm{T}$ cells influence neonatal IgE production. Alternatively, CD21 expression by neonatal and fetal $\mathrm{T}$ cells might simply identify immature $\mathrm{T}$ cells, newly emerged from the thymus, that are poor producers of IL-4 and fail to up-regulate CD40L and thereby fail to support IgE switching. The production of other classes of $\mathrm{Ig}$ are also reduced in the neonate, yet are not regulated by $\mathrm{CD} 21$ and CD23. Thus, expression of CD21 by neonatal $\mathrm{T}$ cells as a marker of T-cell immaturity could be examined postnatally to monitor natural T-cell maturation and to learn whether this is concomitant with maturation of the ability of $\mathrm{B}$ cells to produce all classes of immunoglobulin.

CD23 and CD21 have biologic effects additional to those described for IgE production, including B-cell proliferation, antigen presentation, and the response to soluble antigen, T-B cell adhesion, and apoptosis (33-37). Further functional studies are necessary to elaborate whether CD21 and/or CD23 expression contribute to any of these functions in the neonate. This will be particularly important as CD23 and CD21 have other ligands. CD11b/CD18 is another ligand for CD23 (38) and additional ligands for CD21 include complement components $\mathrm{C} 3 \mathrm{~d}, \mathrm{~g}$ and $\mathrm{iC} 3 \mathrm{~b}$, Epstein Barr virus, and interferon- $\alpha$ (39-41).

The low levels of circulating IgE at term and preterm birth and the diminished ability of neonatal B cells to produce IgE in vitro prompted our study. Interestingly, this may not be a universal property of B cells, as cord blood mononuclear cells from some neonates born in Kenya, where maternal parasitosis still occurs, produced relatively high levels of total and specific IgE (both in vivo and in vitro) (10). Thus, the low level of $\operatorname{IgE}$ production by the majority of neonates may ultimately reflect the absence of environmental/maternally derived factors that provide the trigger for IgE production that could manifest at the level of impaired IL-4 production and poor up-regulation of CD40L. A comparison of the regulatory factors involved in IgE production of infants born to mothers with and without parasitosis - especially T-cell maturity and, therefore, how $\mathrm{T}$ cell help might influence IgE production by B cells - during pregnancy would potentially reveal why $\operatorname{IgE}$ production by Western neonates is so low.

Acknowledgments. The authors thank the staff on the delivery suite at the Princess Anne Hospital, Southampton, for the collection of samples.

\section{REFERENCES}

1. Sutton BJ, Gould HJ 1993 The human IgE network. Nature 366:421-428

2. Bonnefoy JY, Gauchat JF, Life P, Graber P, Mazzei G, Aubry JP 1996 Pairs of surface molecules involved in human IgE regulation: CD23-CD21 and CD40-CD40L. Eur Respir J 9:63s-66s

3. Croner S, Kjellman N-IM, Eriksson B, Roth A 1982 IgE screening in 1701 newborn infants and the development of atopic disease during infancy. Arch Dis Child 57:364-368

4. Magnusson CGM 1988 Cord serum IgE in relation to family history of atopic disease in early infancy. Allergy 43:241-251

5. Dimette JE 1976 Studies of human pregnancy. I. Immunoglobulins attached to the trophoblast. Obstet Gynecol 47:730-732 
6. Avrech OM, Samra Z, Lazarovich Z, Caspi E, Jacobovich A, Sompolinsky D 1994 Efficacy of the placental barrier for immunoglobulins: correlations between maternal, paternal and fetal immunoglobulin levels. Int Arch Allergy Immunol 103:160-165

7. Jones CA, Warner JA, Warner JO 1998 Fetal swallowing of IgE. Lancet 351:1859

8. Miller DL, Hirvonen T, Gitlin D 1973 Synthesis of IgE by the human conceptus. J Allergy Clin Immunol 52:182-188

9. Lima JO, Zhang L, Atkinson TP, Philips J, Dasanayake AP, Schroeder HW 2000 Early expression of iepsilon, CD23 (FcepsilonRII), IL-4Ralpha, and IgE in the human fetus. J Allergy Clin Immunol 106:911-917

10. King CL, Malhotra I, Mungai P, Wamachi A, Kioko J, Ouma JH, Kazura JW 1998 B cell sensitization to helminthic infection develops in utero in humans. J Immunol 160:3578-3584

11. Furuhashi M, Suguira K, Katsumata Y, Oda H, Murase Y, Imai N 1997 Cord blood IgE against milk and egg proteins. Biol Neonate 72:210-215

12. Elliot SR, Roberton DM, Zola H, Macardle PJ 2000 Expression of the costimulator molecules, CD40 and CD154, on lymphocytes form neonates and young children. Hum Immunol 61:378-388

13. Fuleihan R, Ahern D, Geha RS 1994 Decreased expression of the ligand for CD40 in newborn lymphocytes. Eur J Immunol 24:1925-1928

14. Pastorelli G, Rousset F, Pene J, Peronne C, Roncarolo MG, Tovo PA, De Vries JE 1990 Cord blood B cells are mature in their capacity to switch to IgE producing cells in response to inerleukin-4 in vitro. Clin Exp Immunol 82:114-119

15. Durandy A, De Saint Basile G, Lisowska-Grospierre B, Gauchat JF, Forveille M, Kroczek RA, Bonnefoy JY, Fischer A 1995 Undetectable CD40 ligand expression on $\mathrm{T}$ cells and low B cell responses to CD40 binding agonists in human newborns. J Immunol 154:1560-1568

16. Nonoyama S, Penix LA, Edwards CP, Lewis DB, Ito S, Aruffo A, Wilson CB, Ochs HD 1995 Diminished expression of CD40 ligand by activated neonatal T cell. J Clin Invest 95:66-75

17. Splawski JB, Nishioka J, Nishioka Y, Lipsky PE 1996 CD40 ligand is expressed and functional on activated neonatal T cells. J Immunol 156:119-127

18. Suarez A, Mozo L, Gayo A, Simo A, Gutierrez C 2000 Induction of functional CD154 (CD40 ligand) in neonatal T cells by cAMP-elevating agents. Immunology 100:432 440

19. Matthews NC, Wadhwa M, Bird C, Borras FE, Navarrete CV 2000 Sustained expression of CD154 (CD40L) and proinflammatory cytokine production by alloantigen-stimulated umbilical cord blood T cells. J Immunol 164:6202-6212

20. Tang ML, Kemp ASA 1995 Ontogeny of IL-4 production. Pediatr Allergy Immunol 6:11-19

21. Texido G, Eibel H, Le Gros G, van der Putten H 1994 Transgene CD23 expression on lymphoid cells modulates IgE and IgG1 responses. J Immunol 153:3028-3042

22. Riffo-Vasquez Y, Spina D, Thomas M, Gilbey T, Kemeny DM, Page CP 2000 The role of CD23 on allergen-induced IgE levels, pulmonary eosinophilia and bronchial hyperresponsiveness in mice. Clin Exp Allergy 30:728-738

23. Aubry JP, Pochon S, Graber P, Jansen KU, Bonnefoy JY 1992 CD21 is a ligand for $\mathrm{CD} 23$ and regulates IgE production. Nature 358:505-507

24. Fremeaux-Bacchi V, Bernard I, Maillet F, Mani JC, Fontaine M, Bonnefoy JY, Kazatchkine MD, Fischer E 1996 Human lymphocytes shed a soluble form of CD21 (the $\mathrm{C} 3 \delta \gamma /$ Epstein-Barr virus recpetor;CR2) that binds iC3b and CD23. Eur J Immunol 26:1497-1503

25. Mayer RJ, Bologneses BJ, Al-Mahdi N, Cook RM, Flamberh PL, Hansbury MJ, Khandekar S, Appelbaum E, Faller A, Marshall LA 2000 Inhibition of CD23 processing correlates with inhibition of IL-4-stimulated IgE production in human PBL, and hu-PBL-reconstituted SCI mice. Clin Exp Allergy 30:719-727

26. Lee BW, Simmons CT, Wileman T, Geha RS 1989 Intracellular cleavage of newly synthesized low affinity Fc epsilon receptor (Fc epsilon R2) provides a second pathway for the generation of the 28-kDa soluble Fc epsilon R2 fragment. J Immunol 142:1614-1620

27. Oymar K, Laerdal A, Bjerknes R 2000 Soluble CD30 and CD23 in cord blood are not related to atopy in early childhood. Pediatr Allergy Immunol 11:220-224

28. Fischer E, Delibrias C, Kazatchkine MD 1991 Expression of CR2 (the C3 $\delta \gamma / \mathrm{EBV}$ receptor, CD21) on normal peripheral blood T lymphocytes. J Immunol 146:865-869

29. Braun M, Melchers I, Peter HH, Illges H 1998 Human B and T lymphocytes have similar amounts of CD21 mRNA, but differ in the surface expression of the CD21 glycoprotein. Int Immunol 10:1197-1202

30. Delibrias CC, Mouhoub A, Fischer E, Kazatchkine MD 1994 CR1 (CD35) and CD2 CD21) complement $\mathrm{C} 3$ receptors are expressed on normal human thymocytes and mediate infection of thymocytes with osponized human immunodeficiency virus. Eur J Immunol 24:2784-2788

31. Fischer EM, Mouhoub A, Maillet F, Fremeaux-Bacchi V, Krief C, Gould H, Berrih-Aknin S, Kazatchkine MD 1999 Expression of CD21 is developmentally regulated during thymic maturation of human T lymphocytes. Int Immunol 11:18411849

32. Malavasi F, Funaro A, Roggero S, Horenstein A, Calosso L, Mehta K 1994 Human CD38: a glycoprotein in search of a function. Immunol Today 3:95-97

33. Fujiwara H, Kikutani H, Suematsu S, Naka T, Yoshida K, Yoshida K, Tanka T, Suemura M, Matsumoto N, Kojima S, Kishimoto T, Yoshida N 1994 The absence of $\mathrm{IgE}$ antibody-mediated augmentation of immune responses in CD23-deficient mice. Proc Natl Acad Sci U S A 91:6835-6839

34. Reljic R, Cosentino G, Gould HJ 1997 Function of CD23 in the response of human B cells to antigen. Eur J Immunol 27:572-575

35. Grosjean I, Lachaux A, Bella C, Aubry JP, Bonnefoy JY, Kaiserlian D 1994 $\mathrm{CD} 23 / \mathrm{CD} 21$ interaction is required for presentation of soluble protein antigen by lymphoblastoid B cell lines to specific CD4+ T cell clones. Eur J Immunol 24:29822986

36. Croix DA, Ahearn JM, Rosengard AM, Han S, Kelsoe G, Ma M, Carroll MC 1996 Antibody response to a T-dependent antigen requires B cell expression of complement receptors. J Exp Med 183:1857-1864

37. Bjorck P, Elenstrom-Magnusson C, Rosen A, Severinson E, Paulie S 1993 CD23 and CD21 function as adhesion molecules in homotypic aggregation of human B lymphocytes. Eur J Immunol 23:1771-1775

38. Lecoanet-Henchoz S, Gauchat JF, Aubry JP, Graber P, Life P, Paul-Eugene N, Ferrua B, Corbi AL, Dugas B, Platzer-Zyberk C 1995 CD23 regulates monocyte activation through a novel interaction with the adhesion molecules CD11b-CD18 and CD11cCD18. Immunity 3:119-125

39. Weis JJ, Tedder TF, Fearon DT 1984 Identification of a $145000 \mathrm{Mr}$ membrane protein as the C3d receptor (CR2) of human B lymphocytes. Proc Natl Acad Sci U S A 81:881-885

40. Tanner J, Weis JJ, Fearon D, Whang Y, Kieff E 1987 Epstein-Barr virus gp 350/220 binding to the B Lymphocyte $\mathrm{C} 3 \mathrm{~d}$ receptor mediates adsorption, capping and endocytosis. Cell 50:203-213

41. Delcayre A, Salas F, Mathur S, Kovats K, Lotz M, Lernhardt W 1991 Epstein-Bar virus/complement $\mathrm{C} 3 \mathrm{~d}$ receptor is an interferon $\alpha$ receptor. EMBO J 10:919-926 